\title{
Literature Review on the Impacts of Foreign Direct Investment in the Emerging Economy: The Case of Vietnam
}

\author{
Phuong Nam Le \\ University Canada West, Vancouver, Canada \\ Email: lpnam@hotmail.com
}

How to cite this paper: Le, P. N. (2021). Literature Review on the Impacts of Foreign Direct Investment in the Emerging Economy: The Case of Vietnam. Open Journal of Business and Management, 9, 851-857.

https://doi.org/10.4236/ojbm.2021.92044

Received: January 23, 2021

Accepted: March 28, 2021

Published: March 31, 2021

Copyright $\odot 2021$ by author(s) and Scientific Research Publishing Inc. This work is licensed under the Creative Commons Attribution International License (CC BY 4.0). http://creativecommons.org/licenses/by/4.0/

\begin{abstract}
Previous literature has shown positive contributions of foreign direct investment (FDI) on the host countries' economic development. FDI helps to transfer technological know-how and high-quality management to host countries. As a result, benefits from inward FDI include job creation, increased productivity, and higher gross domestic product (GDP). Many researchers have explored the impacts of FDI in different economic sectors such as retailing, manufacturing, banking, and general service. As a result, this study will summarize all of past researches on this topic with the focus on educational sector. This paper will have strong policy implications that can provide the government policy makers knowledge to capture the benefits of FDI in the various sectors of the economy.
\end{abstract}

\section{Keywords}

FDI, Emerging Economies, International Trade, Globalization

\section{Introduction}

Foreign direct investments (FDI) have fueled the economic growth of developing countries (Edrak et al., 2014; Iqbal, Hassan, \& Rawat, 2012; Masron, Zulkafli, \& Ibrahim, 2012). Moreover, in the last few decades, the world has observed a rapid increase in both the flow and the stock of FDI as a result of globalization (Hill \& McKaig, 2015). FDI contributes to the economic growth of host countries in different ways including the transfer of technology, creating jobs, import substitutes, and expanding export volume (Chen, Melachroinos, \& Chang, 2010). Past literatures have explored the impacts of FDI in different sectors of the host countries' economies such as retailing (Iqbal et al., 2012); manufactur- 
ing (Masron et al., 2012); banking (Tare, 2012); mining (Rutaihwa \& Simwela, 2012); telecommunication (Fathima, Ahmed, \& Kumar, 2013); and general service (Edrak et al., 2014). The results showed positive contributions of FDI on sectors and national economies. This paper is going to provide a literature review on the impacts of FDI on emerging economies, especially in the case of Vietnam. The goal is to integrate various pieces of knowledge on this topic to provide a solid foundation for future studies.

\section{Literature Review}

In this section, I review the academic literature regarding the impacts of FDI in the host countries' economies. The resources that I used include mainly peer-reviewed academic journals. First, a brief overview of FDI is provided. Second, I discuss FDI in Vietnam. Third, I present some relationships between FDI and education.

\subsection{Overview of Foreign Direct Investment}

Globalization is the force that integrates national economies around the world (Velde, 2005). It also improves economic development (Iqbal et al., 2012). Furthermore, globalization has led to significant increases in both the flow and the stock of FDI (Hill \& McKaig, 2015). Hill and McKaig (2015) defined FDI as "the acquisition or construction of physical capital by a firm from one (source) country in another (host) country" (p. 228). FDI brings many benefits to the economies of host countries (Büthe \& Milner, 2008). FDI also fills in technological gaps and provides high-skilled labour as well as quality management (Masron et al., 2012). As a result, FDI facilitates job creation, increases GDP, improves infrastructure, promotes competition, and increases the productivity of the host countries (Edrak et al., 2014). Yucel (2014) and Yildirim and Tosuner (2014) confirmed similar findings, stating that FDI helps to grow the economies of developing countries.

Each type of FDI has a different impact on the economies of host countries. There are two major forms of FDI: greenfield and brownfield. As stated by Chen et al. (2010), greenfield FDI involves starting new business facilities in the host countries, while brownfield FDI involves merging or acquiring (M\&A) existing firms in the host countries. Both types of FDI improve the host countries' economies. Greenfield FDI helps to increase capital stock, employment, and outputs; while brownfield contributes to improving productivity (Chen et al., 2010). Other researchers categorize FDI in a different way: horizontal FDI (market-seeking) and vertical FDI (efficiency-seeking; Masron et al., 2012). A more comprehensive categorization of FDI includes natural resource-seeking, market-seeking, efficiency seeking, and strategic asset-seeking (Chen et al., 2010).

Many factors can influence the flow of FDI into a country. According to Büthe and Milner (2008), the flow of FDI is driven by political factors. On the one 
hand, by recognizing the benefits of FDI, many developing countries' governments and policy makers are trying to attract more FDI flow into their countries (Masron et al., 2012). As stated by Wang and Wong (2011), to attract more FDI, the governments provide incentives such as tax breaks and low-interest loans to multinational enterprises (MNEs). On the other hand, some governments have a radical view toward FDI. They see FDI as a tool for capitalist-imperialist home countries. Through FDI, MNEs extract profit from host countries, and take them back to home countries (Hill \& McKaig, 2015). Indeed, Chen et al. (2010) pointed out some negative consequences of FDI on the host countries' economies such as dependence on foreign capital, unstable FDI flow, only focusing on low-tech industry, and threats to domestic firms. Thus, those governments have tried to restrict FDI. However, this radical view has retreated around the world since the early 1990s (Hill \& McKaig, 2015).

The level of economic development influences the amount of FDI that a country receives. According to Chen et al. (2010), most FDI flows into developed economies. Other variables that affect the amount of inward FDI include potential economic development, political stability, democracy, trade agreements, and the level of economic liberalization (Büthe \& Milner, 2008). These factors are positively correlated with the level of inward FDI. Additionally, Büthe and Milner (2008) indicated that international institutions like WTO also facilitate the increase of FDI in developing countries. Lastly, labour quality such as the educational level of the workforce will also affect the amount of inward FDI (Lin, 2011; Yildirim \& Tosuner, 2014).

\subsection{FDI in Vietnam}

Similar to other developing countries, FDI is vital for the Vietnamese economy (Anwar \& Nguyen, 2010). Since economic reform in 1986, the country has started to attract more FDI. FDI into Vietnam grew from 40,000 USD in 1986 to more than 16 billion USD in 2019 (The World Bank, 2021). The benefits of FDI include the transfer of technological know-how, skilled management, and increasing tax revenues for the government (Anwar \& Nguyen, 2010). Furthermore, the United States-Vietnam Bilateral Trade Agreement in 2001 also boosted inward FDI in Vietnam. The agreement gave the most favored nation trade status to Vietnam as well as lower US tariffs on Vietnamese goods from $40 \%$ to $4 \%$ (Büthe \& Milner, 2008: p. 746). Moreover, the agreement also required Vietnam to liberalize and deregulate the market. As a result, foreign investors can monitor and report the Vietnamese government. Consequently, the agreement has caused rapid growth of inward FDI in Vietnam (Büthe \& Milner, 2008).

As a percentage of the GDP, FDI flow into Vietnam is higher than for other countries in the region such as Indonesia, Thailand, and China (Do \& Cao, 2015). In 2005, right before joining WTO, registered capital (FDI) into Vietnam was US $\$ 6$ billion. In 2008, as a member of WTO, Vietnam received an increase 
in registered capital (FDI) up to US $\$ 71.7$ billion. This amount accounted for approximately 80\% of Vietnamese GDP in 2008 (Do \& Cao, 2015). In 2019, the total registered capital became 362.58 billion USD (Ministry of Planning and Investment, 2020). FDI in Vietnam helps to strengthen governance, increase exports, enhance competitiveness, and create more jobs (Do \& Cao, 2015). As stated by Anwar and Nguyen (2010), FDI can have a larger impact in Vietnam if more resources are invested in education and training.

According to the Ministry of Planning and Investment of the Socialist Republic of Vietnam (2020), majority of the FDI investment go into the processing and manufacturing sector. The top three countries that invested heavily in Vietnam in 2019 are South Korea, Hong Kong (China), and Singapore. Sixty-two out of 65 provinces of Vietnam received FDI in that year. However, Hanoi and Ho Chi Minh City topped the list as the destination for foreign investment. These two cities account for more than 40\% of all FDI in 2019 (Ministry of Planning and Investment, 2020).

\subsection{Special Focus: FDI and Education}

The relationship between FDI and education will be discussed in this section. First, I will show the two-way relationship between general FDI (FDI in fields other than education) and the education level of the host country. Second, I will present literature regarding FDI in the educational sector in India.

\subsubsection{FDI in Noneducational Sectors}

There is a two-way relationship between general FDI and education. Lin (2011) showed that education level has a positive impact on the amount of inward FDI in China. Similarly, Zhuang (2013) indicated that education helps to improve technological innovation; thus, education contributes to attracting more foreign investment. At the same time, FDI increases the demand for educated people (Yildirim \& Tosuner, 2014). Moreover, a certain level of education is necessary to capture the benefits of FDI. The labour forces in host countries should have at least 0.58 years of secondary education on average to receive benefits from FDI (Wang \& Wong, 2011). According to Yildirim and Tosuner (2014), MNEs can also provide education and training to the host country. Also, MNEs provide scholarships to gifted or talented students to prepare their own labour force (Yildirim \& Tosuner, 2014). Lastly, FDI is positively related to the public expenditure on education in host countries (Yildirim \& Tosuner, 2014; Zhuang, 2013).

\subsubsection{FDI in the Educational Sector}

The role of education is becoming more important in the knowledge economy (Bloom et al., 2005). It helps developing countries to keep up with advanced economies. FDI in the educational sectors contributes to improving competitiveness and quality of education in developing countries (Suhag \& Rani, 2013). Therefore, developing countries tried to attract foreign higher education institution to invest in their countries by setting up subsidiary centers (Velde, 2005). 
However, there is limited literature on FDI in the educational sector. Most of the available literature is in the Indian context. Thus, the ability to generalize the finding is limited. According to Chitrao (2014), FDI in higher education can be a win-win situation for all stakeholders. Higher education refers to university level education from college diplomas to doctoral degrees (Suhag \& Rani, 2013). Higher education helps to improve economic growth by providing more entrepreneurial activities, better public health, improved technology, better governance, and an improved saving-investment process (Bloom et al., 2005). Thus, investing in higher education will lead to economic prosperity.

Chitrao (2014) discussed the impact of FDI in management education. FDI improved the quality of management education because foreign institutions bring their programs into the country (Chitrao, 2014). It also helps India to export education to other developing countries (Chitrao, 2014). Similar to FDI in other sectors, FDI in education also creates more employment in the host countries. Also, the level of competition is increased, which leads to better quality and lower education costs. Consequently, FDI has made education more affordable to the general public (Chitrao, 2014). Furthermore, educational FDI helps to create better infrastructure and can substitute for government funding in education (Garg, 2013). FDI in education has caused less monetary outflow as the result of Indian students going to school abroad (Garg, 2013). Recognizing the benefits of FDI in education, the Indian government has opened up their higher education sector for foreign investment up to $100 \%$ (Chitrao, 2014).

\section{Conclusion}

FDI has contributed to better economic development around the world. Through the transfer of technological know-how and high-quality management skill, FDI helps to bring many benefits to host countries such as job creation, GDP growth, and higher living standards. The limitation of previous researches is that they did not focus on studying the impact of FDI in any specific sector of the economy. As a suggestion for further study, future research should focus on how FDI can help to transform the educational sector in developing countries. Indeed, education is a critical sector for every nation in the current knowledge economy. It is worthwhile to study the impact of FDI in the educational sector. The study result can help to close the gap of knowledge on the impact of FDI in education. Moreover, the study also has policy implications. Government policy makers can use the knowledge obtained from the proposed study to create appropriate policies to capture the benefits of FDI in the educational sector. As a result, this study might contribute positively to society.

\section{Conflicts of Interest}

The author declares no conflicts of interest regarding the publication of this paper. 


\section{References}

Anwar, S., \& Nguyen, L. P. (2010). Foreign Direct Investment and Economic Growth in Vietnam. Asia Pacific Business Review, 16, 183-202. https://doi.org/10.1080/10438590802511031

Bloom, D. E., Canning, D., \& Chan, K. (2005). Higher Education and Economic Development in Africa. Cambridge, MA: Harvard University.

https://www.aau.org/wp-content/uploads/sites/9/2018/04/Higher-Education-and-Econ omic-Development-in-Africa.pdf

Büthe, T., \& Milner, H. V. (2008). The Politics of Foreign Direct Investment into Developing Countries: Increasing FDI through International Trade Agreements? American Journal of Political Science, 52, 741-762. https://doi.org/10.1111/j.1540-5907.2008.00340.x

Chen, C.-M., Melachroinos, K., \& Chang, K.-T. (2010). FDI and Local Economic Development: The Case of Taiwanese Investment in Kunshan. European Planning Studies, 18, 213-238. https://doi.org/10.1080/09654310903491564

Chitrao, P. (2014). Will FDI in Management Education Make It More Meaningful? Procedia: Social and Behavioral Sciences, 133, 233-239.

https://doi.org/10.1016/j.sbspro.2014.04.189

Do, T. A. T., \& Cao, H. T. (2015). Recognizing the Role of FDI and Institutional Reforms Required in Vietnam. Fulbright Economics Teaching Program. http://www.fetp.edu.vn/attachment.aspx?id=45716

Edrak, B. B., Gharleghi, B., Fah, B. C. Y., \& Tan, M. (2014). Critical Success Factors Affecting Malaysia' SMEs through Inward FDI: Case of Service Sector. Asian Social Science, 10, 131-138. https://doi.org/10.5539/ass.v10n16p131

Fathima, A., Ahmed, B., \& Kumar, S. S. (2013). FDI in Indian Telecom Sector a Perspective. International Journal of Scientific Engineering and Technology, 2, 982-985. http://www.ijset.com/publication/v2/183.pdf

Garg, B. (2013). The Impact of FDI in the Enhancement of Education Sector in India. Pranjana, 16, 68-74.

http://www.indianjournals.com/ijor.aspx?target=ijor:pr\&type=home

Hill, C., \& McKaig, T. (2015). Global Business Today (4th Canadian ed.). Toronto: McGrawHill Ryerson.

Iqbal, B. A., Hassan, M., \& Rawat, B. (2012). FDI in Retail Sector in South Asia: A Case of India. The Journal of World Investment \& Trade, 13, 951-971.

https://doi.org/10.1163/22119000-01306003

Lin, F. (2011). Labor Quality and Inward FDI: A Firm-Level Empirical Study in China. China \& World Economy, 19, 68-86. https://doi.org/10.1111/j.1749-124X.2011.01243.x

Masron, T. A., Zulkafli, A. H., \& Ibrahim, H. (2012). Spillover Effects of FDI within Manufacturing Sector in Malaysia. Procedia: Social and Behavioral Sciences, 58, 1204-1211. https://doi.org/10.1016/j.sbspro.2012.09.1102

Ministry of Planning and Investment of the Socialist Republic of Vietnam (2020). Brief on Foreign Direct Investment of 2019.

http://www.mpi.gov.vn/en/Pages/tinbai.aspx?idTin=45020\&idcm=122\#: :text=In\%202 019\%2C\%20foreign\%20direct\%20investment,capital\%20growth\%20is\%20encouraging \%20achievement

Rutaihwa, J., \& Simwela, A. (2012). Econometric Analysis of FDI in the Mining Sector to Tanzania's Export Capacity. International Journal of Academic Research in Business 
and Social Sciences, 2, 174-191. http://hrmars.com/index.php/pages/detail/IJARBSS

Suhag, V., \& Rani, K. (2013). FDI and Higher Education in India. International Journal of Social Science \& Interdisciplinary Research, 2, 110-113.

http://indianresearchjournals.com/pdf/IJSSIR/2013/August/13.pdf

Tare, A. B. (2012). E-Commerce in India. Golden Research Thoughts, 2, Special Section, 1. Retrieved from EBSCO Host. (Accession \# 84443128)

The World Bank (2021). Foreign Direct Investment, Net Inflows (BoP, Current US\$)— Vietnam. https://data.worldbank.org/indicator/BX.KLT.DINV.CD.WD?locations=VN

Velde, D. W. (2005). Globalisation and Education: What Do the Trade, Investment and Migration Literatures Tell Us? London: Overseas Development Institute.

Wang, M., \& Wong, M. C. S. (2011). FDI, Education, and Economic Growth: Quality Matters. Atlantic Economic Journal, 39, 103-115.

https://doi.org/10.1007/s11293-011-9268-0

Yildirim, D. Ç., \& Tosuner, Ö. (2014). The Effects of FDI on Human Capital Stock in Central Asian Turkic Republics. Eurasian Journal of Business and Economics, 7, 51-60. https://doi.org/10.17015/ejbe.2014.014.03

Yucel, G. E. (2014). FDI and Economic Growth: The Case of Baltic Countries. Research in World Economy, 5, 115-134. https://doi.org/10.5430/rwe.v5n2p115

Zhuang, H. (2013). The Effect of FDI on Local Education Expenditures: Evidence from the United States. Bulletin of Economic Research, 65, 203-224.

https://doi.org/10.1111/j.1467-8586.2011.00404.x 